\title{
Labyrinthe
}

2| 1999

Numéro 2

\section{Peinture religieuse et Etat : le fils prodigue des débuts de la IIIe République}

Commandes et achats de l'Etat français de 1873 à 1879

\section{Emmanuelle Amiot}

\section{(2) OpenEdition \\ Journals}

Electronic version

URL: http://journals.openedition.org/labyrinthe/358

DOI: $10.4000 /$ labyrinthe.358

ISSN: 1950-6031

\section{Publisher}

Hermann

Printed version

Date of publication: 15 January 1999

Number of pages: $40-58$

\section{Electronic reference}

Emmanuelle Amiot, "Peinture religieuse et Etat : le fils prodigue des débuts de la Ille République », Labyrinthe [Online], 2 I 1999, Online since 04 March 2005, connection on 14 May 2019. URL : http:// journals.openedition.org/labyrinthe/358 ; DOI : 10.4000/labyrinthe.358

This text was automatically generated on 14 May 2019.

Propriété intellectuelle 
Peinture religieuse et Etat : le fils prodigue des débuts de la IIIe République

Commandes et achats de l'Etat français de 1873 à 1879

Emmanuelle Amiot 